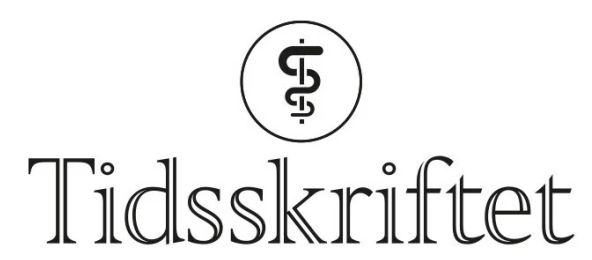

DEN NORSKE LEGEFORENING

\title{
To år med en havarikommisjon i helsetjenesten
}

DEBATT

\section{REIDUN FØRDE}

reidun.forde@medisin.uio.no

Reidun Førde er lege og professor emerita ved Senter for medisinsk etikk, Universitetet i Oslo. Forfatteren har fylt ut ICMJE-skjemaet og oppgir følgende interessekonflikter: Hun er leder for referansepanelet i Statens undersøkelseskommisjon for helse- og omsorgstjenesten.

\section{PÅL IDEN}

Pål Iden er spesialist i samfunnsmedisin og har erfaring fra kommunehelsetjenesten, spesialisthelsetjenesten og helseforvaltningen.

Forfatteren har fylt ut ICMJE-skjemaet og oppgir følgende interessekonflikter: Han er direktør for Statens undersøkelseskommisjon for helse- og omsorgstjenesten.

\section{At helsevesenet trengte en egen «havarikommisjon» møtte motstand da ideen ble lansert. Nå har Statens undersøkelseskommisjon for helse- og omsorgstjenesten vært operativ i to år. Så langt er erfaringene at uheldige hendelser ofte er forårsaket av mangelfull kommunikasjon og samhandling.}

Alvorlige uønskede hendelser var lenge et ikke-tema i helsevesenet. Feil og uhell var skambelagt og ble tiet i hjel. Implisert helsepersonell måtte leve videre med skyldfølelse uten støtte fra kolleger eller tilretteleggelse for å lære av hendelsen (1). Siden slutten av 9otallet har erkjennelsen av den innebygde feilbarligheten i all medisinsk virksomhet økt. Dette innebærer at hendelsene ikke gjemmes bort, men tvert imot løftes fram og granskes både for læring og kvalitetsforbedring. Slik kan pasienter, pårørende og helsepersonell få nødvendig støtte i etterkant av hendelsene (므). Men fortsatt er det belastende å varsle om forhold som truer god kvalitet, fortsatt er det å være involvert i hendelser med pasientskader skambelagt og fortsatt beskriver helsepersonell manglende støtte fra kolleger og ledelse som belastende (3). Det tar tid å endre kultur.

\section{Undersøkelseskommisjonens arbeid}


Før Statens undersøkelseskommisjon for helse- og omsorgstjenesten ble opprettet i 2019, møtte tanken om en uavhengig undersøkelseskommisjon for helsevesenet betydelig motstand fra tjenesten selv (4). Et av argumentene var at Norge allerede har et godt utbygget kvalitetsarbeid. Kommisjonens erfaring er imidlertid at flere av systemene ikke fungerer optimalt og heller ikke alltid kommuniserer godt nok innbyrdes og ut til ansvarlig helsepersonell.

«Oppdraget til kommisjonen er å bidra til lcering etter alvorlige uønskede hendelser»

Oppdraget til kommisjonen er å bidra til læring etter alvorlige uønskede hendelser. Den skal sette enkelthendelser inn i en tematisk ramme, se hendelsene i sammenheng og analysere bakenforliggende strukturer som kan forårsake eller beskytte mot alvorlige uønskede hendelser (4). . Undersøkelsesprosessen bygger på stor grad av involvering av pasienter/brukere, pårørende, personell og ledere i helsetjenesten, samt kompetansemiljøer, yrkesorganisasjoner, forvaltningsorganer og myndigheter.

Kommisjonen gjennomgår alle varsler om alvorlige hendelser til Helsetilsynet og kan også granske forhold på eget initiativ. Målet er å aktivisere ansvarlige aktører utover det aktuelle hendelsesstedet og stimulere til faglig interesse, fagdiskusjoner og deling av erfaringer. Kommisjonens anbefalinger og læringsnotat utformes i samspill med helsetjenesten selv, brukere og ansvarlige myndigheter, slik at kommisjonens bidrag spiller på lag med annet kvalitetsarbeid. En av de største utfordringene er hvordan alvorlige enkelthendelser eller varsler om alvorlige trusler mot kvaliteten i helsetjenesten kan beskrives og løftes fram for dem som har kompetanse, makt og myndighet til å skape nødvendige endringer.

\section{Fragmentering og silotenkning}

Så langt har kommisjonen gjennomgått 1461 helsetilsynsvarsler og mottatt 169 egne bekymringsmeldinger. Seks omfattende rapporter er ferdigstilt med råd tilbake til fagmiljø og myndigheter. Psykiske helsetjenester og selvmord synes å være overrepresentert i varslene om alvorlige hendelser. Mange av de alvorlige hendelsene rammer pasienter med et særlig vanskelig utgangspunkt, som kronisk psykisk sykdom, utviklingshemming, funksjonssvikt som ikke er fanget opp, eller fremmedkulturell bakgrunn.

Vi ser i disse sakene at det ikke gir mening å lete etter én skyldig. Årsakene til uønskede hendelser er flere og sammensatte. Sakene avspeiler medisinens kompleksitet - moderne medisin er effektiv, komplisert og risikofylt. Mange pasienter har kroniske og komplekse tilstander som stiller store krav til dem som skal hjelpe. En hyppig årsak til at noe går galt er ansvarspulverisering eller manglende samhandling og kommunikasjon mellom helsepersonell og ulike nivåer i helsetjenesten. Viktig informasjon fra pårørende fanges ikke opp eller går tapt underveis, og sammen med manglende informasjonsdeling mellom første- og annenlinjetjenesten gir det svakhet i diagnostikk og forsinket behandling. Mangelfull samhandling fører også til unødig ressurskrevende behandling ved at alvorlige tilstander ikke fanges opp tidsnok. Dette er systemfeil knyttet til kultur og holdninger.

«Når tjenesten blir målt på økonomiske rammer og røde tall, kan kvalitet og pasientsikkerhet lett bli ofret»

Andre eksempler på systemfeil er varsler fra ansatte om mangelfulle rutiner, uverdige forhold for pasientene eller for trange rammer for arbeidet som over tid ikke gripes fatt i. Når helsepersonells kritikk ignoreres av ledelsen, oppstår «husblindhet» eller moralsk 
utbrenthet, det vil si at man gradvis aksepterer uakseptable forhold. Følgene er gjerne størst for svake pasientgrupper uten taleføre pårørende.

\section{God samhandling er et ledelsesansvar}

Så hvorfor får ikke manglende samhandling og manglende kommunikasjon større oppmerksomhet, også der dette gjelder mellom avdelinger i samme institusjon? Vårt inntrykk er at kvalitetsarbeid og tilsynsarbeid ofte er avgrenset til å se på en bestemt avdeling og et fagfelt. Mye læring kan gå tapt dersom man ikke ser på hele pasientreisen, også mellom aktørene. Samhandlingsreformen hadde riktige begrunnelser og store ambisjoner, men har i for liten grad ført til bedre og tryggere helsetjenester. Silotenkning har som resultat at selv $i$ et lite land som Norge er det store regionale forskjeller på kvaliteten og omfanget av helsetjenester. I en av rapportene til kommisjonen ble det for eksempel avdekket store regionale forskjeller på behandling av henvisninger til barne- og ungdomspsykiatrien ((5), s. 27-31). Å gjøre for mye eller for lite av noe er også et kvalitetsproblem.

Det er et ledelsesansvar å sørge for gode systemer, særlig rundt pasientene med komplekse tilstander (므). God samhandling er en viktig del av dette. Det er også ledelsens ansvar å håndtere varsler riktig, uten å skule til omdømme. Når tjenesten blir målt på økonomiske rammer og røde tall, kan kvalitet og pasientsikkerhet lett bli ofret. Når det da går galt, er det lett å peke på de som sist var involvert, mens systemsvikten forblir i mørket.

\section{LITTERATUR}

1. Aasland OG, Førde R. Impact of feeling responsible for adverse events on doctors' personal and professional lives: the importance of being open to criticism from colleagues. Qual Saf Health Care 2005; 14: 13-7. [PubMed][CrossRef]

2. Lindekleiv H, Johannessen T, Bugge E. Varsler om alvorlige hendelser fra norske helseforetak 201117. Tidsskr Nor Legeforen 2019; 139. doi:10.4045/tidsskr.17.1118. [PubMed][CrossRef]

3. Førde R, Aasland OG. Is imperfection becoming easier to live with for doctors? Clin Ethics 2017; 12: 31-6. [PubMed][CrossRef]

4. Tajik AA. Fra skyld og skam til læring og forbedring. Tidsskr Nor Legeforen 2019; 139. doi: 10.4045/tidsskr.19.0557. [PubMed][CrossRef]

5. Statens undersøkelseskommisjon for helse- og omsorgstjenesten. Ungdom med uavklart tilstand. Rapport 3-2020.https://ukom.no/rapporter/ungdom-med-uavklart-tilstand/ungdom-med-uavklarttilstand Lest 16.6.2021.

6. Hermansen M. Pasientsikkerhet - alltid første punkt på agendaen. Tidsskr Nor Legeforen 2019; 139: 667.

Publisert: 20. juli 2021. Tidsskr Nor Legeforen. DOI: 10.4045/tidsskr.21.0233

Mottatt 22.3.2021, første revisjon innsendt 16.6.2021, godkjent 22.6.2021.

(C) Tidsskrift for Den norske legeforening 2023. Lastet ned fra tidsskriftet.no 26. april 2023. 